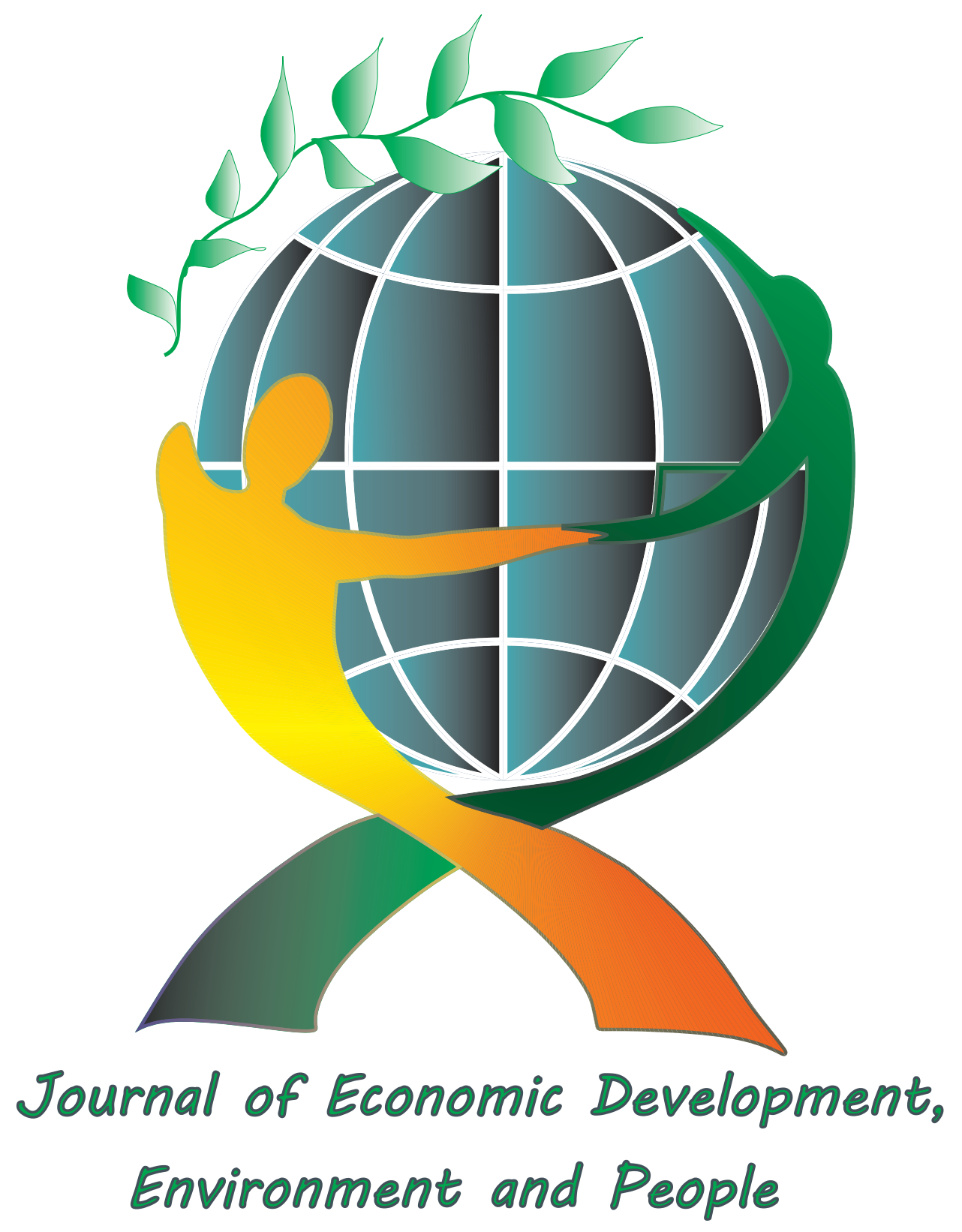

(online) $=$ ISSN $2285-3642$

ISSN-L = $2285-3642$

Volume 3, Issue 1

2014

http://jedep.spiruharet.ro 
(online) = ISSN $2285-3642$

ISSN-L = 2285 - 3642

Journal of Economic Development, Environment and People

Volume 3, Issue 1, 2014

URL: http://jedep.spiruharet.ro

e-mail: office_jedep@spiruharet.ro

\section{Copyright@2014 Editura FRM}

All rights reserved. No part of this publication may be reproduced, stored, transmitted or disseminated, in any form, or by any means, without prior written permission from Editura FRM, to whom all requests to produce copyright material should be directed, in writing.

\section{Editor in Chief:}

Manuela Epure

Editing:

Marga Constantin

Gabriela Dinca

Graphics:

Arch.student Adelina Dima

Web_administrator:

Lecturer Rocsana Bucea-Manea-Toniş 


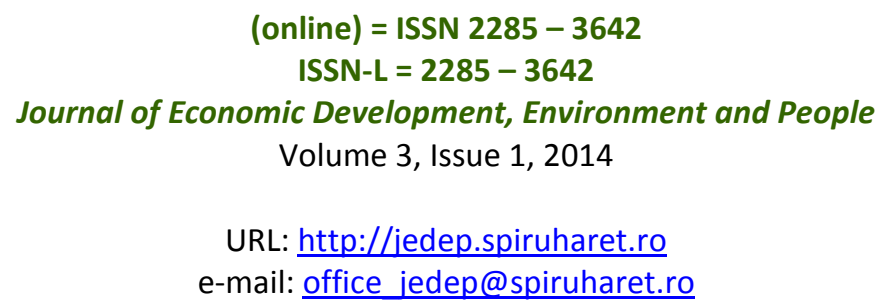

\section{Table of Content}

1. Professor Manuela Epure, PhD., Editor-in-chief - Foreword .

2. Tania Georgia Viciu, Antoniu Ovidiu Balint, Professor Carmen Eugenia Costea, PhD - Quality of life: a multifaceted approach

3. Professor Cicilia Ionescu, PhD - Management Strategies and Environmental Accounting in Economic Entities. A Contribution to Sustainable Development

4. Associated Professor Fooarea Georgescu, PhD, Professor Cicilia IONESCU, PhD ${ }^{2}$ - Harmonization of accounting in the process of globalization of economic activities

5. Lecturer Rocsana Bucea-Manea-Toniş, PhD cd, Lecturer Radu Bucea-Manea-Țoniş, PhD - Actual cash financing situation of SMEs in Romania and further recommendations

6. Professor Cicilia Ionescu, PhD, Associated Professor Fooarea Georgescu, PhD - Estimation and valuation in accounting 


\author{
(online) $=$ ISSN $2285-3642$ \\ ISSN-L = 2285- 3642 \\ Journal of Economic Development, Environment and People \\ Volume 3, Issue 1, 2014 \\ URL: http://jedep.spiruharet.ro \\ e-mail: office jedep@spiruharet.ro
}

\title{
Actual cash financing situation of SMEs in Romania and further recommendations
}

\author{
Lecturer Rocsana Bucea-Manea-Joniş, PhD cd ${ }^{1}$, Lecturer Radu Bucea-Manea-Joniş, PhD, ${ }^{2}$ \\ ${ }^{1}$ Faculty of Marketing and International Business, Spiru Haret University \\ rocsanamanea.mk@spiruharet.ro
}

\begin{abstract}
.
The world is experiencing a revolution in the digital and mobile technologies, with more information available more quickly and for more media than ever before. In this context, SMEs can turn to cloud solution. Although the advantages of using the cloud are compelling for SMEs this shift involves financial costs. In Romania the rate of access to funds is very low. In this context, SMEs need additional assistance to obtain funding.
\end{abstract}

Keywords: SME financing European funds, cloud computing, Document Type Definition, XML, SOAP/REST

JEL Codes: M15 IT Management

\section{Economic indicators of SMEs in Romania}

"Romanian SMEs use to produce a 70\% of the country's GDP and provides about $70 \%$ of employment labor" in 2008. [www2]. Currently these percents do not exceed 65\%. We consider the SME a sector of strategic interest for the economy, being the most active sector of the economy. According to the White Paper on SMEs in Romania, 2008 Edition, $98.2 \%$ of all companies active in the country, achieved a turnover of up to two million and $92 \%$ of these were micro enterprises. If by 2008 all macroeconomic indicators (GDP, CA, unemployment) had an upward trend, since then they are in constant decline, as an effect of the crisis event. 


\author{
(online) $=$ ISSN $2285-3642$ \\ ISSN-L = 2285 - 3642 \\ Journal of Economic Development, Environment and People \\ Volume 3, Issue 1, 2014 \\ URL: http://jedep.spiruharet.ro \\ e-mail: office jedep@spiruharet.ro
}

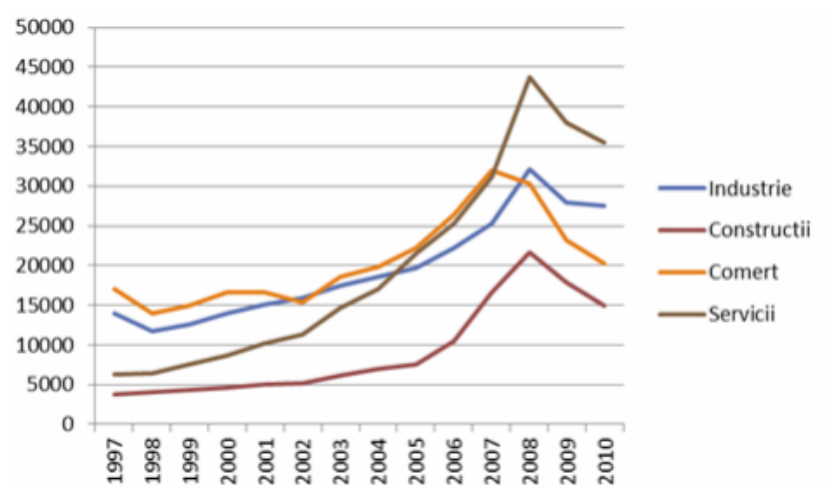

Fig. 1: Estimating the contribution of SMEs to economic growth in the medium term [www3]

GDP is a very sensitive to commerce domain. Pushing it by $1 \%$ would bring a significant increase $(1.7 \%)$ of the overall GDP. [www3]

In the last three years many SMEs (about 90,000) became insolvent. Of these 19,900 companies became insolvent in 2009, 21,700 in 2010, 24,078 in 2012 and about 28,000 in 2013 shows the National Office of the Trade Registry. From all the Romanian firms entered insolvency only 4-6\% avoided bankruptcy compared to $20 \%$ of EU firms. Among these companies that became insolvent over $70 \%$ were in the field of carry trade, transportation / warehousing, manufacturing and construction.

However in 2011-2012 were established more than 250,000 companies, particularly in the wholesale trade, agriculture, forestry / fishing, and professional, scientific and technical field. [www4]

As may be seen in the figure 2, the estimated GDP growth is roughly equal (about $2 \%$ ) for all European countries, except for Lithuania and Latvia (over 4\%). It is interesting to know if the growth of GDP is due to exports, tourism, or internal services or other fields of activity. Romania, along with Great Britain, Sweden and Malta, have a lower unemployment rate of $8 \%$. This indicator would be satisfying if unemployment in Romania would be evenly calculated. However taking into account the people who support themselves from farming (villagers) and the seasonal working migrants gone abroad which are not included in the statistics, unemployment in Romania could exceed even that of Ireland and Slovakia, which is greater than $12 \%$. The purchasing power of money in Romanian is lower even those in Lithuania and Latvia, where inflation in these countries is higher than $2 \%$. 


\author{
(online) $=$ ISSN $2285-3642$ \\ ISSN-L = $2285-3642$ \\ Journal of Economic Development, Environment and People \\ Volume 3, Issue 1, 2014 \\ URL: http://jedep.spiruharet.ro \\ e-mail: office jedep@spiruharet.ro
}

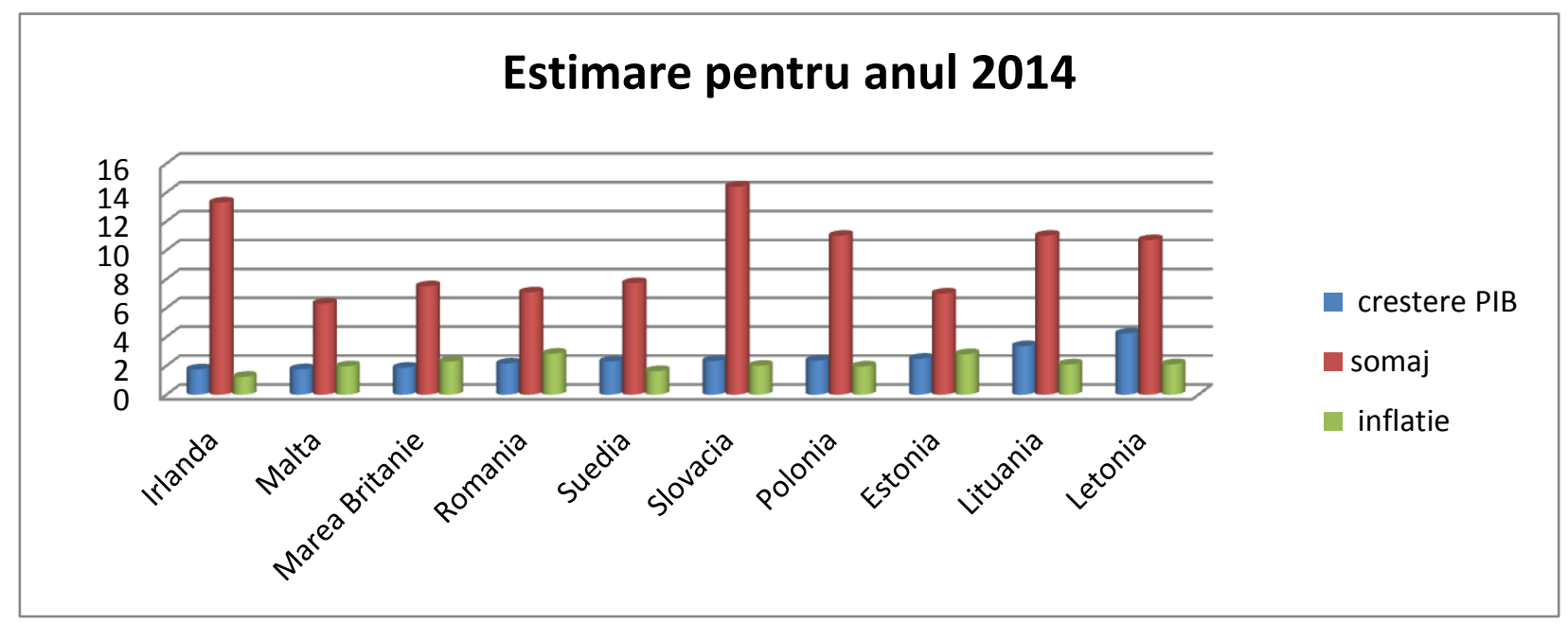

Fig. 2: Estimated GDP growth, unemployment and inflation for 2014 [www4]

Romanian National Prognosis Commission estimated the values of GDP growth for the period 20142015, will be even higher than in 2008. The figure 3 shows that GDP is formed particularly in the BucharestIlfov region where values are even twice larger than those formed in the region of Southeastern Romania.

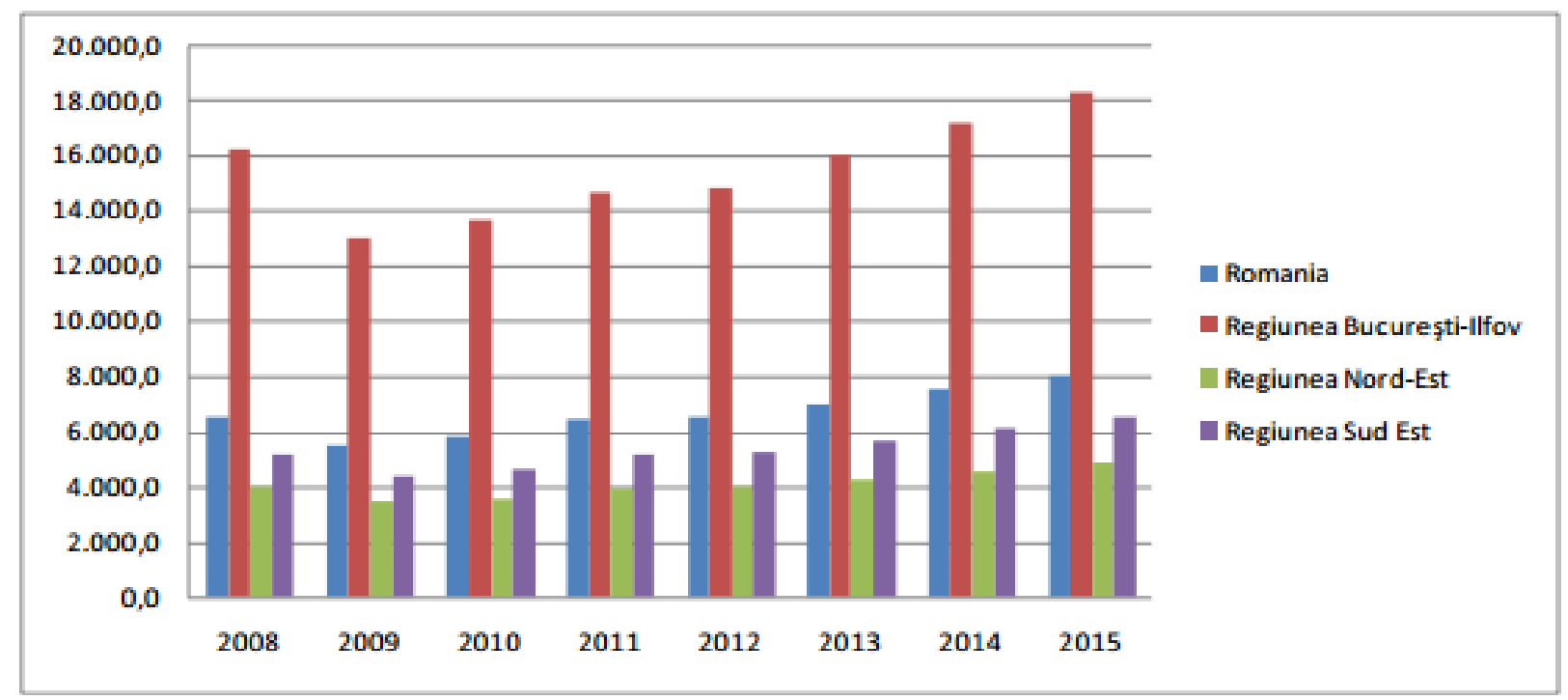

Sursa: Prognoza în profil teritorial 2012-2015, Comisia Natională de prognoză

Fig. 3: Trend GDP growth for 2015 [NPC, 2012] 


\author{
(online) $=$ ISSN $2285-3642$ \\ ISSN-L = 2285-3642 \\ Journal of Economic Development, Environment and People \\ Volume 3, Issue 1, 2014 \\ URL: $\underline{\text { http://jedep.spiruharet.ro }}$ \\ e-mail: office jedep@spiruharet.ro
}

\title{
2. Sources of funding for SMEs
}

Attracting capital is one of the preconditions for starting a successful business (especially for SMEs) and to ensure its durable development. Using its own resources or loans it is often insufficient to new firms, called start-ups, excepting those with strong growth potential. Risk aversion often leads investors and banks to avoid financing start-up companies. On the other hand, many entrepreneurs need advice over the advantages and disadvantages of different forms of financing and look out for ways to present investment projects to potential investors.

With the advancement in the life cycle, the SMEs gradually adjust the capital structure [La Rocca, 2011]. Over years some SMEs establish a positive history thus having the ability to provide security to investors and banks. This serves to enhance the creditworthiness of the company and, therefore, attract the attention of investors who could invest money in this business. As a result, companies are starting to replace domestic sources of external finance, including venture capital and bank loans to name a few of them. In the more advanced stages of their life cycle when SMEs become more visible, they may develop access to securitized debt and publicly listed equity markets. [Abdulsaleh, 2013]

SMEs can apply to internal and external funding sources:

A. Internal funding sources have some advantages like preserving the independence and financial autonomy because it creates additional obligations (interest, collateral) as a reliable means of financial support for the company's needs. Also, internal sources have associated disadvantages because the owners have fewer funds to invest in other more profitable activities than the current one.

Internal funding sources are:

1. Contributions from owners or associate members, i.e. equity finance. During the initial stages of development of SMEs, internal equity financing is most often used as the company cannot prove that it can return a loan but having a very good business plan. Fortunately not all entrepreneurs fail to convince potential donors with their business plans, so they have no need to resort to personal savings at this early stage (start- up). In later stages of development SMEs tend to reduce dependence on equity financing and start looking for alternative channels for raising capital. Internally generated profits and venture exemplifies only two other financing options that SMEs may use as they grow. [Abdulsaleh, 2013]

2. Resources generated by the company (profit).

\section{B. Sources of external funding}

Loan required for an SME activity is obtained analyzing the indicators for development costs, which are influenced by the future development of the SME. This need should be determined at the planning stage of development. Depending on the characteristics of these necessities, the company has to develop a funding policy. External funding is required if the SME does not have sufficient internal resources to cover the investment required for the planned activities. [Onicioiu, 2012]

External financing of SMEs include:

1. loans - granted by banks to SMEs 


\author{
(online) $=$ ISSN $2285-3642$ \\ ISSN-L = $2285-3642$ \\ Journal of Economic Development, Environment and People \\ Volume 3, Issue 1, 2014 \\ URL: $\underline{\text { http://jedep.spiruharet.ro }}$ \\ e-mail: office jedep@spiruharet.ro
}

2. grants - Romania 's accession in EU has brought many opportunities for financial support for small business (Horizon 2020)

3. capital market instruments - securitized debt and publicly listed equity markets.

4. government assistance and government initiatives

5. Islamic finance for SMEs - The rapid growth of Islamic finance has triggered a potentially promising new trend in finance, which is not limited to Islamic countries because Islamic finance has spread to non-Muslim countries with significant Muslim populations, including the U.S., UK and Australia.

If you consider the age of SMEs, it is found that [Onicioiu, 2012] :

a. firms less than five years, largely are self-financing;

b. companies operating between 5 and 10 years using factoring, grants or loans from specialized financial institutions;

c. companies operating between 10 and 15 years, were financed by issuing shares on the stock market, they turned to credits and leasing, loans from specialized financial institutions and some have accessed the National Credit Guarantee Fund for SMEs;

d. Companies operating over 15 years were financed by issuing shares on the stock market and grants.

\title{
2.1. Stage accessing European funds by Romanian companies
}

Structural Consulting Company Consulting ${ }^{\text {TM }}$ Group during 7 to 14 February 2011, implemented a survey on the difficulties of accessing funds, through the portal www.fonduri-structurale.ro. Responses came from a number of 314 SMEs. General conclusions drawn from the survey in many situations were major delays in the evaluation phase, delays of payments (pre and repayments) even 15 months in some cases, poor communication involving authority's management processes, lack of transparency reimbursement mechanism, problems in accessing loans for financing, high interest rates on loans obtained, sometimes causing termination of the contract. Another obstacle to applicants and beneficiaries was more than expected postponement of the launch funding lines cases where companies have invested time, money and human resources in writing projects that came to be "obsolete" over time. Lack of predictability was also highlighted through long periods of time between project approval and contracting them effective.

Overall Romania receives 26.1 billion Euros in 5 structural funds: Cohesion, Regional Development, Social, Environment and Rural Development. Besides Cohesion Policy and the Common Agricultural Policy funds will be directed under Territorial Cooperation Policy, where we have operational cooperation programs with Hungary and Bulgaria [IUCR, 2013]

Degree of accessing European Founds is almost 19\%. (fig. 4) 


$$
\begin{gathered}
\text { (online) }=\text { ISSN } 2285-3642 \\
\text { ISSN-L = 2285 - } 3642
\end{gathered}
$$

Journal of Economic Development, Environment and People

Volume 3, Issue 1, 2014

URL: http://jedep.spiruharet.ro

e-mail: office jedep@spiruharet.ro

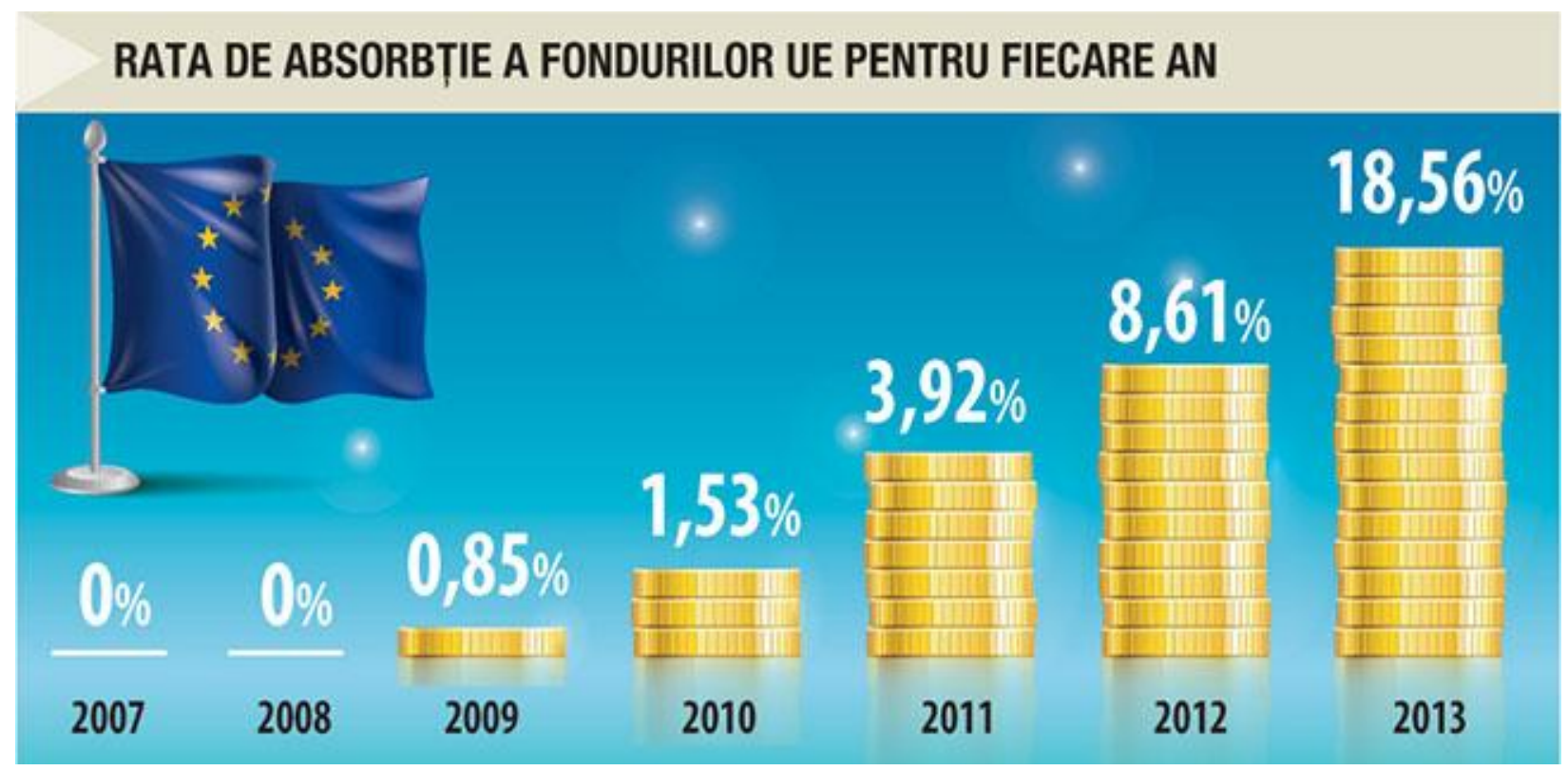

Fig. 4: Rates of absorption of European funds [Cepu, 2014]

\section{EU}

$138683.4 \mathrm{M} \in$

\section{România}

\section{$3445.5 \mathrm{M} €$}

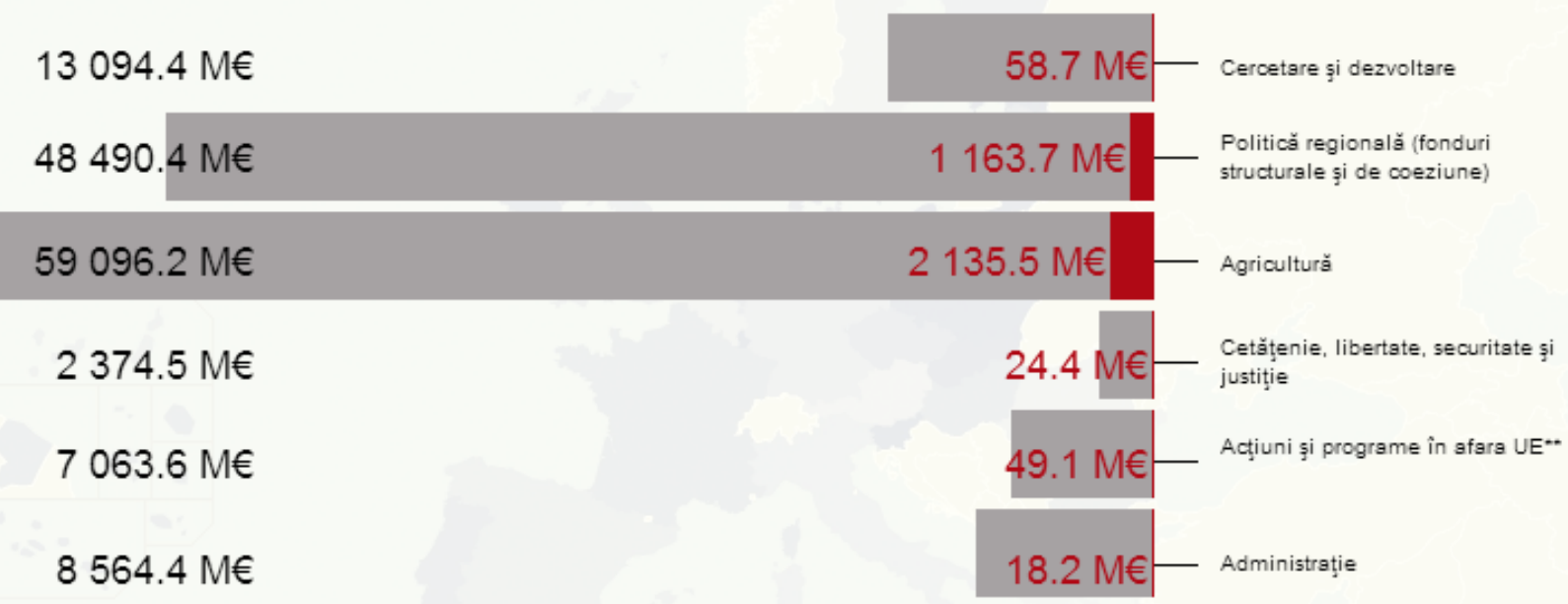

Fig. 5: The total European spending [Cepu, 2014] 


\author{
(online) $=$ ISSN $2285-3642$ \\ ISSN-L = 2285-3642 \\ Journal of Economic Development, Environment and People \\ Volume 3, Issue 1, 2014 \\ URL: $\underline{\text { http://jedep.spiruharet.ro }}$ \\ e-mail: office jedep@spiruharet.ro
}

\title{
3. Cloud computing for Romanian SMEs
}

Currently, the market tends to be dominated by cloud computing solutions that are reducing costs, as applications, technologies and data are available on a server, and clients pay only service packages tailored to business conducted in the form of subscription. Joining the cloud brings other advantages such as minimal initial costs of implementation (not unbalancing the company's cash flow by hiring qualified IT personal for application development), maintenance may be kept remote thus not requiring in-house specialists, provide access to the new technologies in the field, etc.

Cloud computing solutions respond well to the requirements of SMEs, as they have less financial and human resources allocated for integration of information technology in their work field, so they have no supplementary costs. The cloud solutions enable purchase of services with a small initial investment, without involving in-depth knowledge of IT solutions which is well tailored to SMEs.

In order to take advantage of cloud computing paradigm an ordinary company must first check the enterprise architecture framework, focusing on methodologies, the knowledge database and the management processes. These should be compliant to principles and international standards for IT governance.

For business processes to be supported by data and application components at any organizational level - commercial, technical, operations and financial - several directions must be followed:

1. Identify key business domains, core functions and owners to create a responsibility map;

2. Increased attention and effort towards real time processing;

3. Database server consolidation;

4. Common infrastructure for development.

IBM Institute for Business Value research reveals that six key attributes of cloud can be used to stimulate business model innovation path: the cost of flexibility, scalability, business, market adaptability, complexity hidden variability due to events and business ecosystem connectivity [Saul, 2012]. These attributes can be optimized by consultancy business strategy and technology for the next generation cloud service delivery platform for SMEs (Ex. IBM SmartCloud, offers a robust set of services computing, storage, backup, SAP, security and unified communications), designing and implementing cloud computing.

It was found that firms with a coherent strategy for integrating digital can successfully transform business models and may provide new directions for the benefit of entire industries by adapting the client and model transformation at the operational level. The first goal can be achieved using the new capabilities of mobility, interactivity and access to information. The second requires the integration of all business activities and Reflectors how data on these activities are correlated optimal [Saul, 2011].

Depending on the technology they have access to SMEs join the Internet virtual space to expand their business processes on foreign markets. At this point, the probability of SMEs to expand is shrinking for certain domestic market, causing the companies to seek for new foreign markets. [Kamakura, 2012] 


\author{
(online) $=$ ISSN $2285-3642$ \\ ISSN-L = 2285- 3642 \\ Journal of Economic Development, Environment and People \\ Volume 3, Issue 1, 2014 \\ URL: $\underline{\text { http://jedep.spiruharet.ro }}$ \\ e-mail: office jedep@spiruharet.ro
}

\title{
4. Case study
}

Many cloud systems bases on SOAP/REST technologies which relies on XML formatted data message change. A problem may rise to ensure data persistence in such way to interrogate large historical build data packages. One way to solve this issue is to use OWL or any other ontology tool to read directly the XML files into taxonomic/hierarchical directories from the knowledge databases. A simpler way is to map the XML file into a relational database that grows accordingly to the frequency of changed messages. After this stage some may easily query the whole database using common SQL sentences.

Data mapping transforms an XML document into relational tuples and inserts them into the relational database whose schema is generated in the schema mapping phase. A main factor in mapping successfully XML data structures into fixed-length field tables is the DTD schema. DTD stands for Document Type Definition and is meant to define the legal building blocks of an XML document and the relationship between the various elements that form the documents. Also, DTD allows computers to check that each component of document occurs in a valid place within the document. [www5]

One example of DTD file which describes a nested XML file may be seen in the following table:

\begin{tabular}{|c|c|}
\hline DTD File & XML File \\
\hline $\begin{array}{l}<\text { ?xml version="1.0" encoding="UTF- } \\
8 \text { "?> } \\
<\text { !DOCTYPE notes SYSTEM "Note.dtd" }> \\
<\text { notes }> \\
<\text { note } \\
<\text { to }>\text { Radu</to }> \\
<\text { from }>\text { Rocsana }<\text { from }> \\
<\text { body }> \\
<\text { p }>\text { Don't forget me this weekend! }</ \text { p }> \\
<\text { p }>\text { I'll call Friday anyway... }<\text { p }> \\
</ \text { body }> \\
</ \text { note }> \\
</ \text { notes }>\end{array}$ & $\begin{array}{l}\text { <! DOCTYPE notes } \\
\text { [ } \\
<\text { !ELEMENT notes (note*) } \\
<\text { !ELEMENT note (to, from, body) }> \\
<\text { !ELEMENT to (\#PCDATA) }> \\
<\text { !ELEMENT from (\#PCDATA) }> \\
<\text { !ELEMENT body (p+)> } \\
<\text { !ELEMENT p (\#PCDATA) }> \\
\text { ] }>\end{array}$ \\
\hline
\end{tabular}

The XML file is used to insert data into generated database schema. This trivial data structure may be split into two indexed tables, one containing the heading info, the other the body text content, like in the picture below: 


\section{(online) $=$ ISSN $2285-3642$ \\ ISSN-L = $2285-3642$ \\ Journal of Economic Development, Environment and People \\ Volume 3, Issue 1, 2014}

URL: http://jedep.spiruharet.ro

e-mail: office jedep@spiruharet.ro

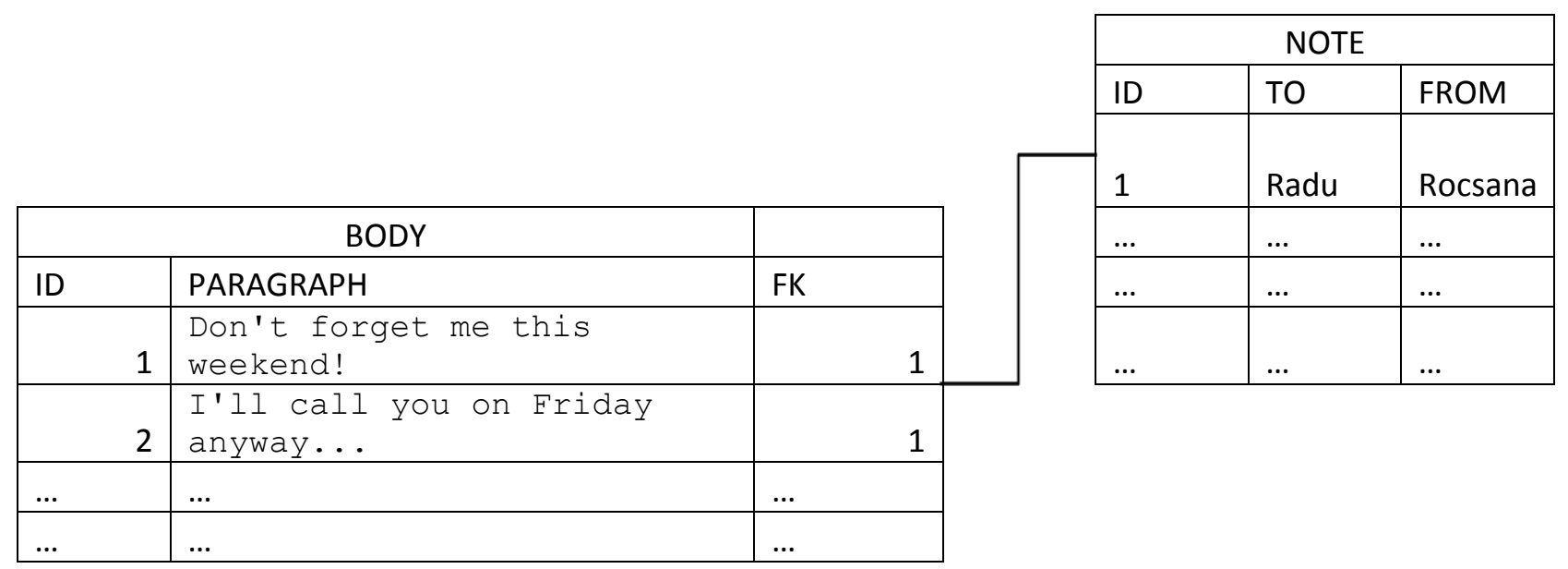

Fig. 6: Data Mapping

SAXParser is used to fetch data from XML file. The code for parsing the XML tree and generating the relational tuples is shown below:

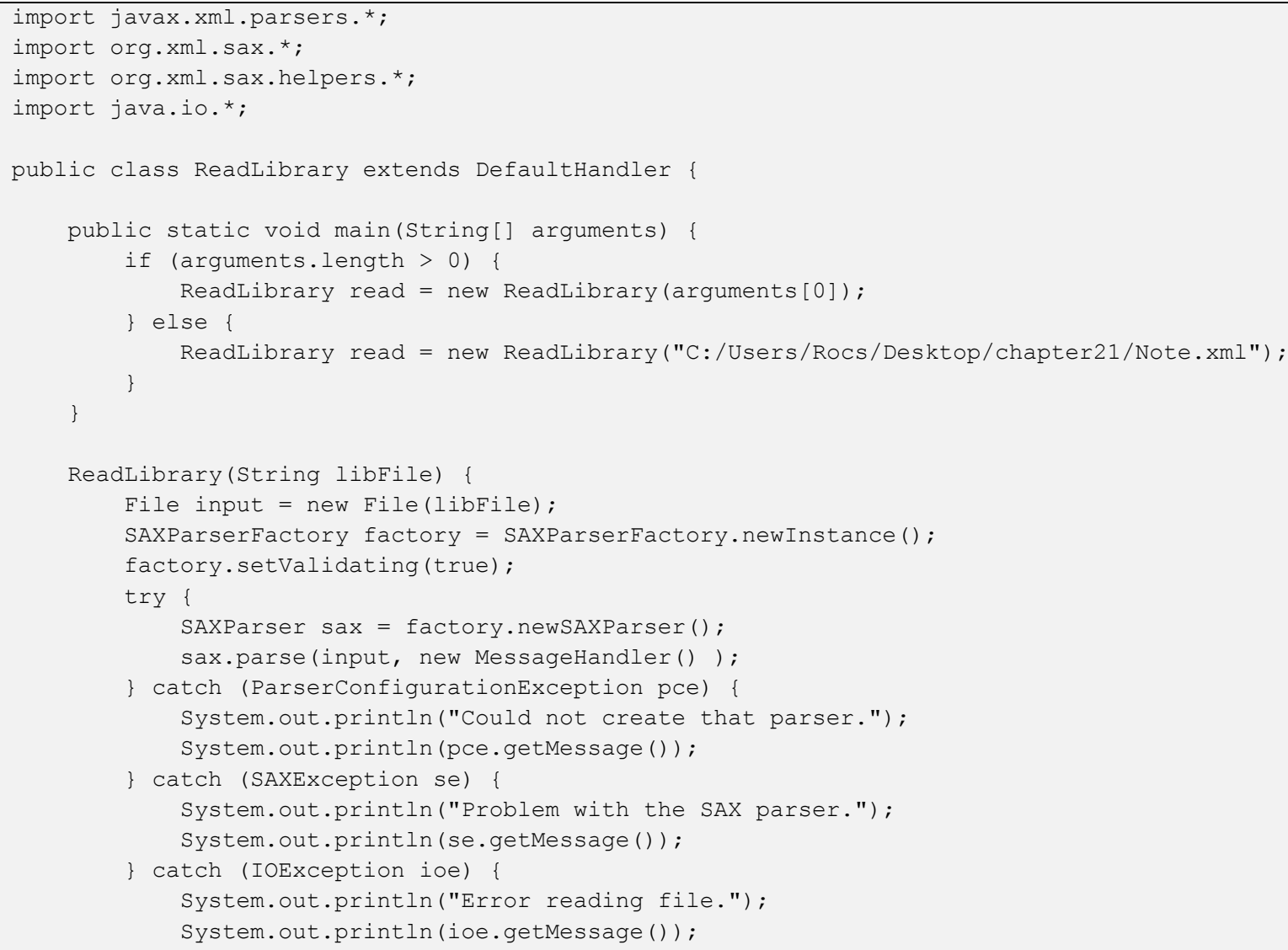




\section{(online) $=$ ISSN $2285-3642$ \\ ISSN-L = 2285 - 3642 \\ Journal of Economic Development, Environment and People \\ Volume 3, Issue 1, 2014}

URL: http://jedep.spiruharet.ro

e-mail: office jedep@spiruharet.ro

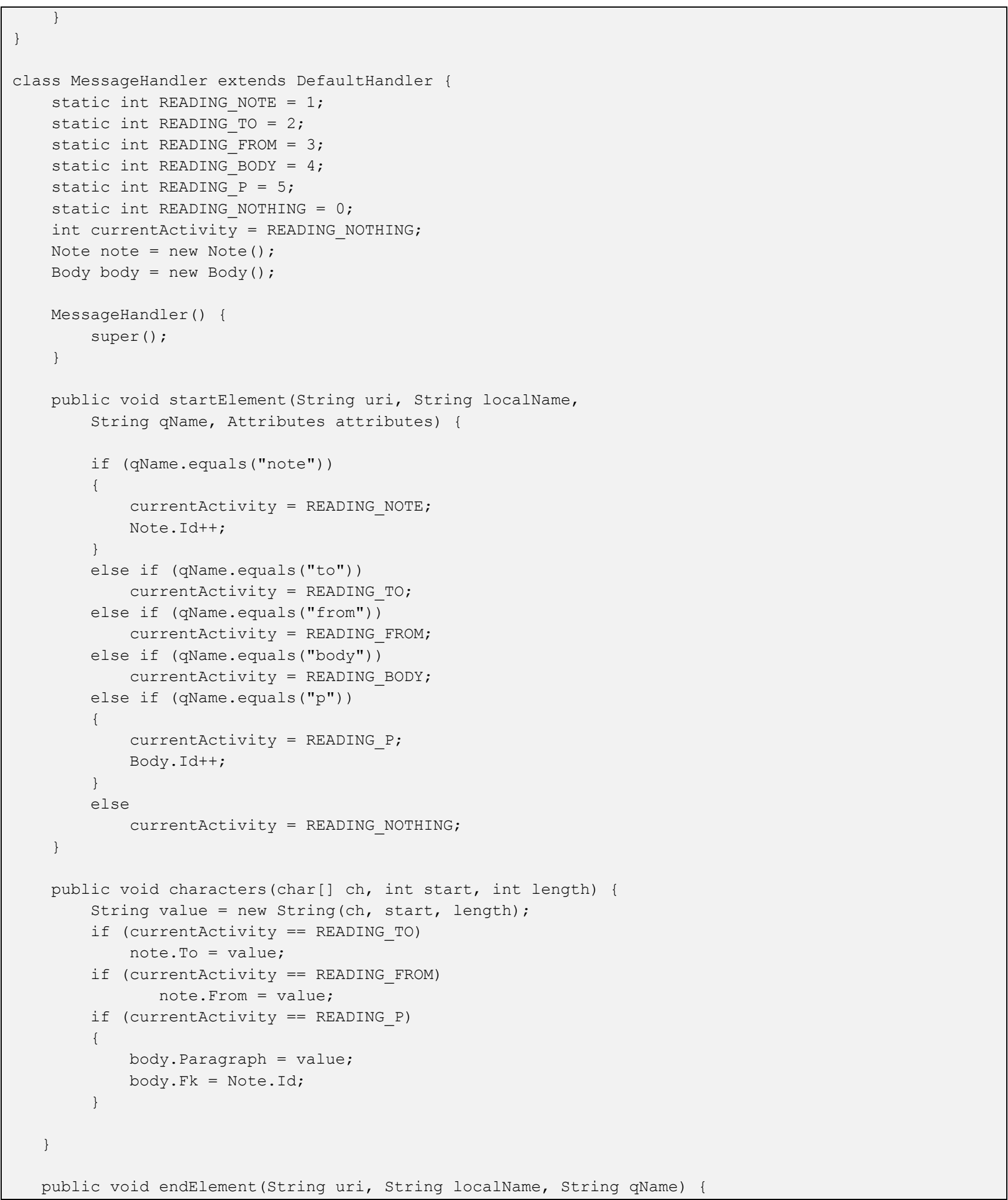




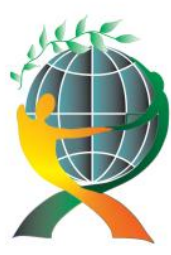

$$
\begin{gathered}
\text { (online) }=\text { ISSN } 2285-3642 \\
\text { ISSN-L = 2285 - } 3642
\end{gathered}
$$

Journal of Economic Development, Environment and People

Volume 3, Issue 1, 2014

URL: http://jedep.spiruharet.ro

e-mail: office jedep@spiruharet.ro

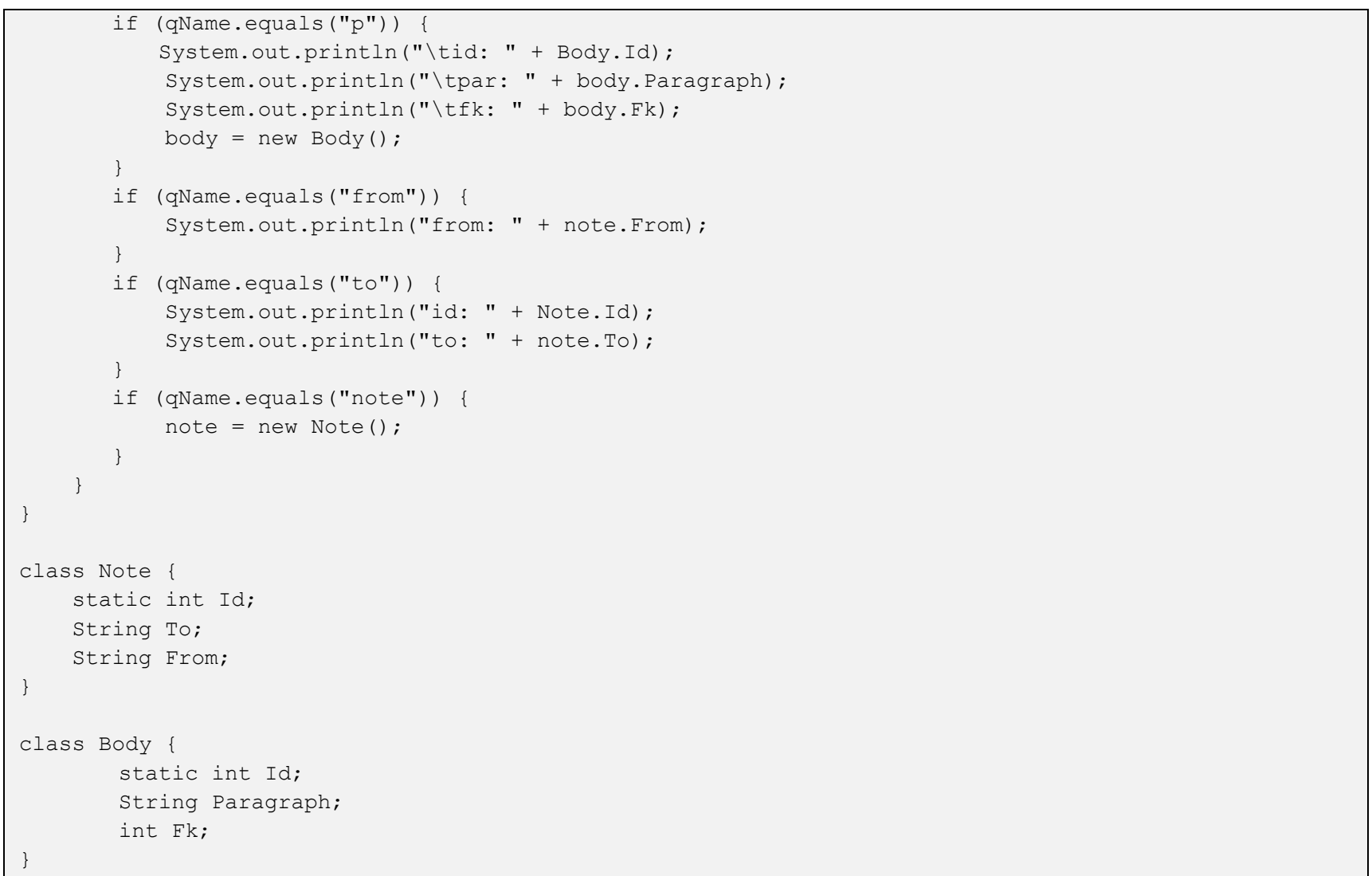

The result is shown in the next figure:

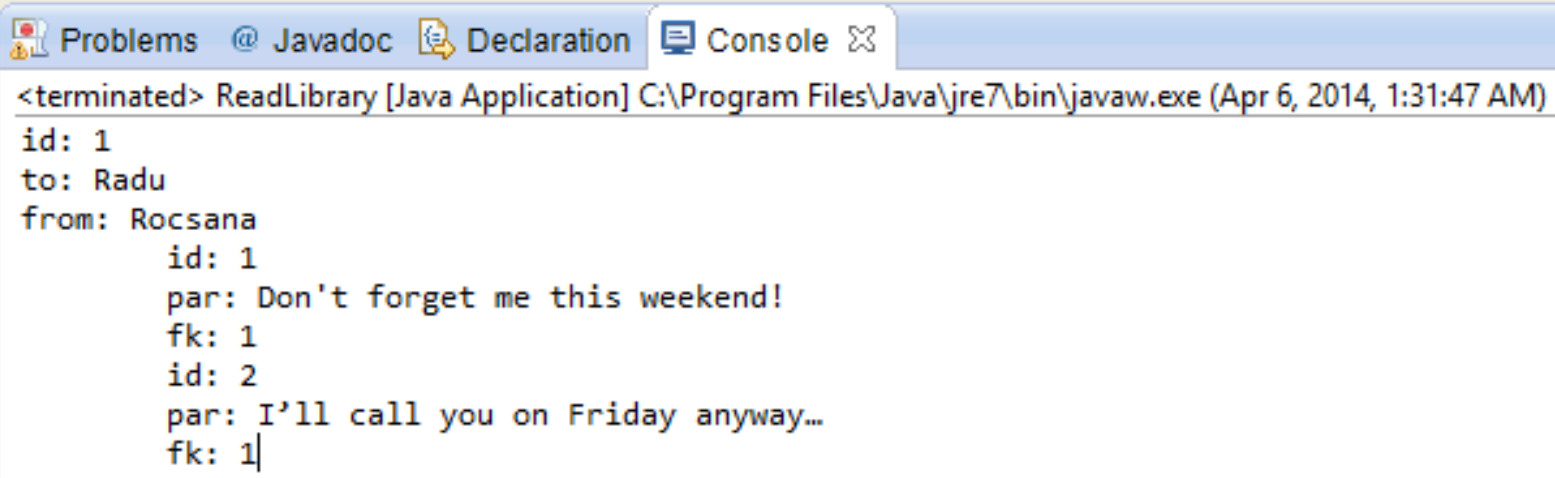

Fig. 7: Eclipse IDE Java Console Result 


\author{
(online) = ISSN $2285-3642$ \\ ISSN-L = $2285-3642$ \\ Journal of Economic Development, Environment and People \\ Volume 3, Issue 1, 2014 \\ URL: $\underline{\text { http://jedep.spiruharet.ro }}$ \\ e-mail: office jedep@spiruharet.ro
}

\title{
5. Conclusions:
}

Given the high rate of insolvency for Romanian SMEs and the low rate of accessing European funds it is necessary to increase the pace towards e-business and the cloud/grid computing solutions seem to be the appropriate answer to the virtual organization that groups different kinds of resources (financial, human, data, etc.) scattered on the globe for a common lucrative goal.

\section{Acknowledgement}

This work is supported by the Romania's Operational Program for Human Resource Development (POSDRU), financed from the European Social Fund and the Romanian Government under the contract number POSDRU ID 134393 (cempdi.pub.ro/knowledge).

\section{References:}

[1] [Abdulsaleh, 2013] Abdulsaleh, Abdulaziz M; Worthington, Andrew C., Small and MediumSized Enterprises Financing: A Review of Literature, International Journal of Business and Management 8.14 (2013): 36-54.

[2] [Alderete, 2013] Alderete, María Verónica - DO INFORMATION AND COMMUNICATION TECHNOLOGY ACCESS AND INNOVATION INCREASE OUTSOURCING IN SMALL AND MEDIUM ENTERPRISES? Journal of Information Systems and Technology Management: JISTEM 10.2 (May-Aug 2013): 303-322

[3] [CNIPMMR 2012 - 2016] Strategia Consiliului Naţional al Întreprinderilor Private Mici şi Mijlocii din România $2012-2016$

[4] [CNP, 2012] Comisia Nationala de Prognoza http://www.cnp.ro/inovatie/docs/seminar-studii-24-022012/prezentare studiu 3.pdf

[5] [CEPU, 2014] Centru de Elaborare Proiecte Unionale http://cepu.ro/public/ro/actualitati.php

[6] [IUCR, 2013] Innovation Union Competitiveness Report 2013 http://ec.europa.eu/research/innovationunion/pdf/competitiveness report 2013.pdf

[7] [Kamakura, 2012] Kamakura, Wagner A; Ramón-jerónimo, María A; Vecino Gravel, Julio D. - A dynamic perspective to the internationalization of small-medium enterprises, Academy of Marketing Science. Journal 40.2 (Mar 2012): 236-251.

[8] [Menardi, 2014] Menardi, Giovanna; Torelli, Nicola - The effect of training set selection when predicting defaulting small and medium-sized enterprises with unbalanced data, The Journal of Credit Risk 9.4 (Winter 2013/2014): 47-62.

[9] [Onicioiu, 2012] Oncioiu, Ionica - Small and Medium Enterprises' Access to Financing - A European Concern: Evidence from Romanian SME, International Business Research, 5.8 (Aug 2012): 47-58.

[10] [PSMEF, 2010-2013] Planului Strategic al Ministerului Economiei şi Finanţelor http://discutii.mfinante.ro/static/10/Mfp/planstrategic/Anexa ordin Planstrategic MFP 2010 2013.pdf

[11] [Saul, 2011] Saul J. Berman, Ragna Bell - Digital Transformation - Creating new business models where digital meets physical, IBM Global Services, 2011 


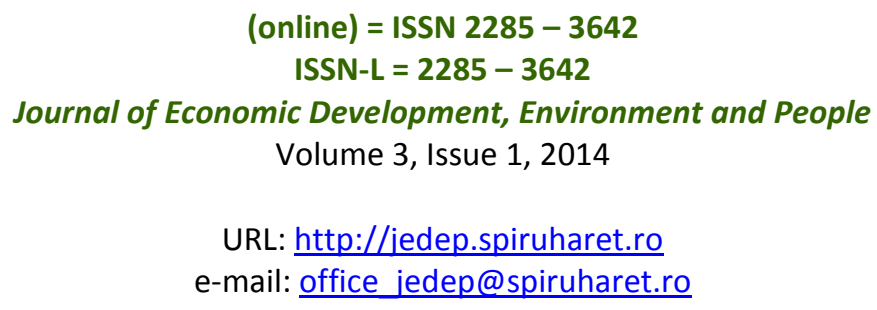

[12] [Saul, 2012 ] Saul J. Berman, Lynn Kesterson - Townes, Anthony Marshall, Rohini Srivathsa, The power of cloud - Driving business model innovation, IBM Global Services, 2012

[13] [www2] Ce sunt IMM-urile - http://www.startups.ro/analize/ce-sunt-imm-urile

[14] [www3] Wall Street Journal -http://www.wall-street.ro/articol/Legal-Business/117460/insolventele-în2011.html?utm source=newsletter-daily-20120302\&utm medium=email\&utm content=daily20120302\&utm campaign=Newsletter-Daily,

[15] [www4] Wall Street Journal http://www.wall-street.ro/slideshow/Economie/161584/tarile-ue-cu-cele-maibune-estimari-de-crestere-ale-pib-in-2014/4/locul-7-romania.html\#anchor-of-navigator

[16] [www6] Georgia State University - $\quad$ Advanced $\quad$ Database Systems http://www.cs.gsu.edu/yli/teaching/Spring08/DB/slides/bhavin.ppt 